\title{
Longitudinal Distribution of Hypostomus punctatus (Osteichthyes, Loricariidae) in a Coastal Stream from Rio de Janeiro, Southeastern Brazil
}

\author{
Márcia S. de Menezes ${ }^{1}$ and Érica P. Caramaschi \\ ${ }^{1}$ Depto. de Zoologia, Universidade Federal do Paraná, CP 19020, CEP 81531-990, Curitiba-PR, Brazil; ${ }^{2}$ Depto. de \\ Ecologia, Instituto de Biologia, Universidade Federal do Rio de Janeiro, CP 68020, CEP 20941-970, Rio de Janeiro- \\ RJ, Brazil.
}

\begin{abstract}
Hypostomus punctatus was collected between June/1987 and July/1988, in three sampling stations with different features, along the Ubatiba stream (Maricá, Rio de Janeiro state). Sampling stations 2 and 3 were more similar (50\% similarity) to each other. The species was frequent and persistent in all sampling stations. The size varied from 1.0 to $22.2 \mathrm{~cm}$. The occurrence of different size classes along the stream was probably related to the kind of environment. Young forms prevailed in the total sample and were mainly collected next to the submersed riparian vegetation. Adults occurred just in sampling stations 1 and 2, and were found most often in rapids with rocky bottom, and in pools among submersed branches.
\end{abstract}

Key-words: fish, Hypostomus punctatus, longitudinal distribution, structure in size, coastal streams.

\section{INTRODUCTION}

The occupation and distribution of fishes along a river can be influenced by many abiotic and biotic factors, such as temperature, $\mathrm{pH}$, salinity, substrate type, food availability, and reproductive strategies. Many authors have studied this in North America (Sheldon, 1968, Whiteside \& McNatt, 1972), and in tropical fauna (Lowe McConnell (1975), Power (1984) and Lyons \& Schneider (1990). Brazilian streams, however, have not been so well studied in this regard. Some authors, e.g. Costa (1984), Uieda (1984), Garutti (1988), Aranha et al. (1993), Buck \& Sazima (1995), and Aranha \& Caramaschi (1997) have studied this subject. Some of them thought that fish distribution was related to physical traits (e.g. Aranha \& Caramaschi, op. cit., who suggested the occurrence of four poecilids according to water along a stream).

The Loricariidae family is a great diversified freshwater fish group with morphological changes as the mouth like a sucker, which allows their adhesion to the substrate (Schäefer, 1987). The Hypostominae subfamily has been studied concerning its bionomy (e.g. Agostinho et al., 1986, Mazzoni \& Caramaschi, 1997). Hypostomus was considered as detritivore and important to the process of recycling nutrients (Angelescu \& Gneri, 1949). It was first recorded in the Ubatiba stream by Costa (1984), who has also studied its occupation and feeding in another stream in Rio de Janeiro state (Costa, 1987).

The Ubatiba stream is a small coastal stream which has been studied to improve the knowledge of dynamic of fish species and their persistence in unstable environments as this stream. The tropical rains, mainly in summer time, generally cause flash floods which disestablish the habitats, carrying down physical structures (branches, sand, etc), and biotic ones (eggs, larvae, food, etc). In this stream, this phenomenon has been very usual and its fish populations present several tactics to keep themselves alive. In this article, we present the longitudinal distribution of Hypostomus punctatus and its structure in size along the Ubatiba stream.

\section{MATERIALS AND METHODS}

Hypostomus punctatus was collected during June/1987 to July/1988 at three sampling points in the Ubatiba stream (municipal district of Maricá,

\footnotetext{
${ }^{1}$ Author for correspondence
} 
Rio de Janeiro state), with a hand net $(5 \mathrm{~mm})$ and sieves $(1.65 \mathrm{~mm})$ in a 200 meters extension. The current velocity (flotation method) and area were estimated in each sampling point every month. The data of June/1988 were excluded because of a storm. Substrate type, colour of water, riparian vegetation and human activity were classified. The similarity between the sampling points was analysed by the simple matching similarity coefficient (Krebs, 1989), which allowed the cluster analyses (UPGMA, Romesburg, 1990).

The fishes were fixed in formalin $10 \%$ and preserved in alcohol $70^{\circ}$ GL. Some of them were kept in the Ichthyologic Collection in Museu Nacional do Rio de Janeiro (MNRJ 11568). The persistence of the species in the sampling points was calculated according to Dajoz (1978), and its occurrence was monthly determined in all sampling points. The fishes were measured (standard length in $\mathrm{cm}$ ). We adopted 15 length classes of $1.5 \mathrm{~cm}$ (Table 1). The structure in size was determined for each sampling station by the occurrence of the length classes. The ratio between young and adults was verified and tested by the $\chi^{2}$ for $\mathrm{k}$ independent samples (Siegel, 1981). Adults were considered from $11.5 \mathrm{~cm}$ (according to Menezes \& Caramaschi, 1994).

Table 1 - Standard length classes $(\mathrm{cm})$ of Hypostomus punctatus.

\begin{tabular}{c|c|c|c}
\hline Classes & $\begin{array}{c}\text { Length } \\
\text { Amplitude }\end{array}$ & Classes & $\begin{array}{c}\text { Length } \\
\text { Amplitude }\end{array}$ \\
\hline 1 & $1,0 \mid-2,5$ & 9 & $13,0 \mid-14,5$ \\
2 & $2,5 \mid-4,0$ & 10 & $14,5 \mid-16,0$ \\
3 & $4,0 \mid-5,5$ & 11 & $16,0 \mid-17,5$ \\
4 & $5,5 \mid-7,0$ & 12 & $17,5 \mid-19,0$ \\
5 & $7,0 \mid-8,5$ & 13 & $19,0 \mid-20,5$ \\
6 & $8,5 \mid-10,0$ & 14 & $20,5 \mid-22,0$ \\
7 & $10,0 \mid-11,5$ & 15 & $22.0 \mid-23.5$ \\
8 & $11,5 \mid-13,0$ & & \\
\hline
\end{tabular}

\section{STUDY SITE}

The Ubatiba stream belongs to the lagoon system of the municipal district of Maricá, RJ $\left(22^{\circ} 45^{\prime} \mathrm{S}\right.$, $\left.42^{\circ} 45^{\prime} \mathrm{W}\right)$. It possesses $15 \mathrm{~km}$ of extension approximately. Its head-water is located at approximately $540 \mathrm{~m}$ of altitude and its mouth in the Maricá lagoon, a region of lakes. From the head-water to the mouth, the stream presents several physicographic features, and it crosses areas of intense agricultural and urban exploration in the town of Maricá. The three sampling stations were distributed in different areas from the river, in gradient head-water-mouth, according to Aranha \& Caramaschi (1997): one in the superior area (station 1, at approximately $60 \mathrm{~m}$ of altitude, with small falls and marginal pools, whose current velocity varied between 0.28 and $1.31 \mathrm{~m} / \mathrm{s}$ ), another one midway (station 2, with small rapids and pools, current velocity between 0.22 and 1.22 $\mathrm{m} / \mathrm{s}$ ) and the last one, in the inferior area (station 3, with flow almost laminate, current velocity between 0.55 and $1.04 \mathrm{~m} / \mathrm{s}$, located close to the urban area of the town) characterised in the Table 2.

Table 2 - Features of the three sampling stations along the Ubatiba stream.

\begin{tabular}{|c|c|c|c|c|}
\hline \multirow{2}{*}{\multicolumn{2}{|c|}{ Features }} & \multirow{2}{*}{\multicolumn{3}{|c|}{ Stations }} \\
\hline & & & & \\
\hline Substrate & \begin{tabular}{|l}
.sand \\
.pebble \\
.rock \\
\end{tabular} & $\begin{array}{l}X \\
X \\
X \\
\end{array}$ & $\begin{array}{l}\mathrm{X} \\
\mathrm{X}\end{array}$ & $\mathrm{X}$ \\
\hline Depth & $\begin{array}{l}\text { till } 1 \mathrm{~m} \\
. \text { upper } 1 \mathrm{~m}\end{array}$ & $X$ & $X$ & $\mathrm{X}$ \\
\hline $\begin{array}{l}\text { Current } \\
\text { Velocity }\end{array}$ & $\begin{array}{l}\text { lotic } \\
\text { lotic/lentic }\end{array}$ & $\mathrm{X}$ & $\mathrm{X}$ & $X$ \\
\hline $\begin{array}{l}\text { Colour of } \\
\text { Water }\end{array}$ & $\begin{array}{l}\text {.clear } \\
\text {.almost dark } \\
\text {.dark }\end{array}$ & $\mathrm{X}$ & $\mathrm{X}$ & $X$ \\
\hline Altitude & $\begin{array}{l}. \text { till } 10 \mathrm{~m} \\
.10 \text { to } 40 \mathrm{~m} \\
. \text { upper } 40 \mathrm{~m}\end{array}$ & $X$ & $X$ & $\mathrm{X}$ \\
\hline Vegetation & $\begin{array}{l}\text { herbaceous/ } \\
\text { shrubs } \\
\text {.trees }\end{array}$ & $\begin{array}{l}X \\
X\end{array}$ & $X$ & $\mathrm{X}$ \\
\hline $\begin{array}{l}\text { Human } \\
\text { Activity }\end{array}$ & $\begin{array}{l}\text { agricultural } \\
\text {.urban }\end{array}$ & & $\mathrm{X}$ & $\begin{array}{l}\mathrm{X} \\
\mathrm{X}\end{array}$ \\
\hline
\end{tabular}

The similarity analysis showed station 1 as clearly different from the others; stations 2 and 3 presented likeness of $50 \%$ (Fig. 1).

\section{RESULTS}

A total of 686 fishes was collected, 58 from station 1, 274 from station 2 and 354 from station 3. The distribution of the monthly relative occurrence in 
the three stations is presented in Fig. 2. It can be observed that about $80 \%$ of the captures in station 1 were from February to July/1988; and at station 3 , approximately $70 \%$ of the fishes were captured between October/1987 and March/1988. Hypostomus punctatus was $100 \%$ constant in the stations, except in station $1(85.7 \%)$.

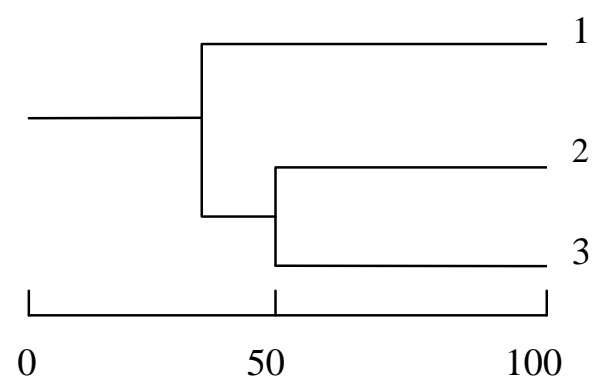

Figure 1 - Group of sampling stations according to the features of environments.

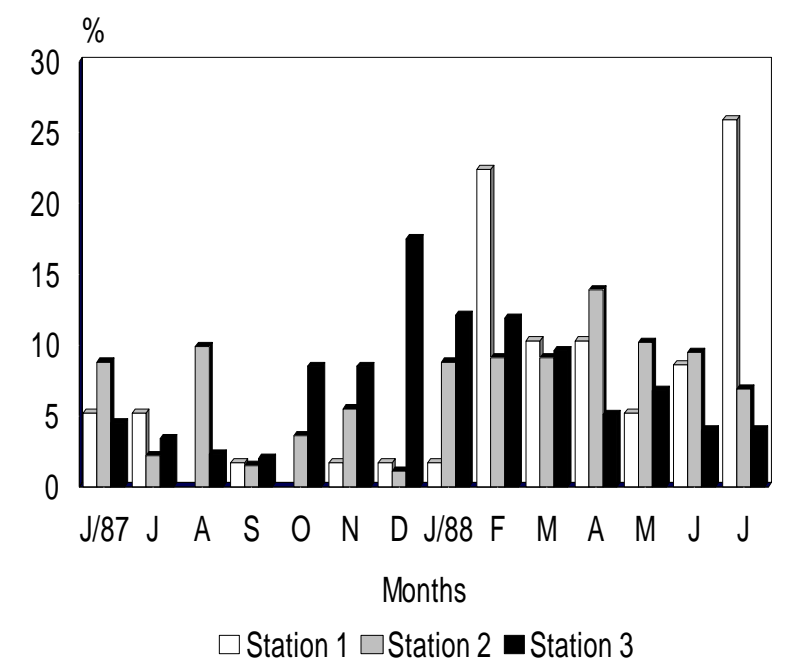

Figure 2 - Monthly occurrence of Hypostomus punctatus in three sampling stations.

For the sample as a whole, the standard length varied, from $1.0 \mathrm{~cm}$ to $22.2 \mathrm{~cm}$. Station 1 presented fishes of all length classes; the best represented class was of $8.5 \mathrm{~cm}$ to $10.0 \mathrm{~cm}$, and it was the only station to record individuals with $\mathrm{Lp}$ superior to $19.0 \mathrm{~cm}$ (Fig. 3). In station two, 93\% of individuals were smaller than $8.5 \mathrm{~cm}$; the best represented class was of $2.5 \mathrm{~cm}$ to $4.0 \mathrm{~cm}$ (Fig. 3). In station three, $76.5 \%$ of fishes were between 1.0 and $4.0 \mathrm{~cm}$; the best represented class was of $1.0 \mathrm{~cm}$ to $2.5 \mathrm{~cm}$, and the biggest fish belonged to the class of 10.0 to $11.5 \mathrm{~cm}$ (Fig. 3).
At station 3, the occurrence of the class 1.0 to 2.5 $\mathrm{cm}$ was superior to $50 \%$ a month, in November and December, and in February and March (Table 3). Station 1 presented $75 \%$, on the average, of young; station 2, 97\% and in station 3, adults didn't occur (Fig. 4). The distribution of young and adults was statistically related to the sampling station $\left(\chi^{2}=107.8, \mathrm{p}<0.05\right)$.

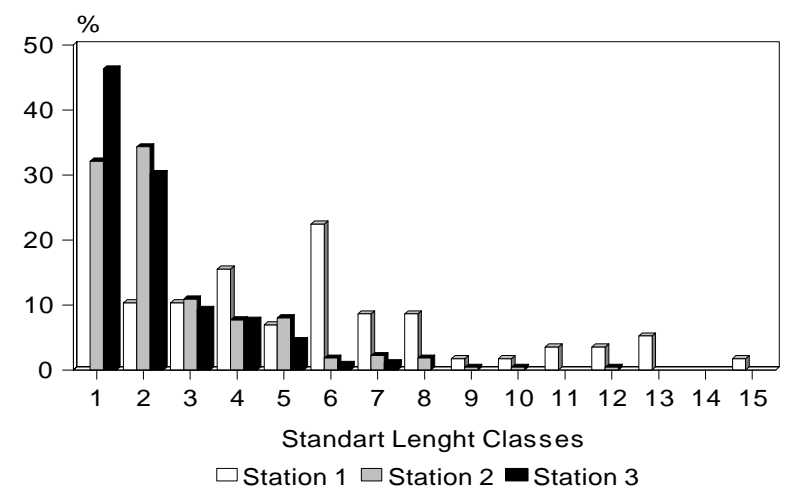

Figure 3 - Occurrence of standard length classes of Hypostomus punctatus in three sampling stations.

Table 3 - Monthly percent occurrence of standard length classes of Hypostomus punctatus in station three.

\begin{tabular}{l|c|c|c|c|c|c|c|c}
\hline & 1 & 2 & 3 & 4 & 5 & 6 & 7 & 8 \\
\hline J & 37,5 & 50 & 12,5 & & & & & \\
J & 8,3 & 58,3 & 16,7 & 8,3 & 8,3 & & & \\
A & 12,5 & 75 & & & 12,5 & & & \\
S & & 85,7 & & & 14,3 & & & \\
O & 43,3 & 6,7 & 23,3 & 10 & 10 & 3,3 & & 3,3 \\
N & 53,3 & 30 & 3,3 & 10 & 3,3 & & & \\
D & 62,9 & 12,9 & 6,4 & 8,1 & 6,4 & & 3,2 & \\
J & 44,2 & 23,2 & 7 & 7 & 7 & 9,3 & 2,3 & \\
F & 57,1 & 23,8 & 7,1 & 7,1 & 4,8 & & & \\
M & 58,8 & 17,6 & 8,8 & 5,9 & 8,8 & & & \\
A & 22,2 & 38,9 & 16,7 & 11,1 & 11,1 & & & \\
M & 29,2 & 54,2 & 8,3 & 8,3 & & & & \\
J & 7,1 & 85,7 & 7,1 & & & & & \\
J & 7,1 & 71,4 & 14,3 & 7,1 & & & & \\
\hline
\end{tabular}

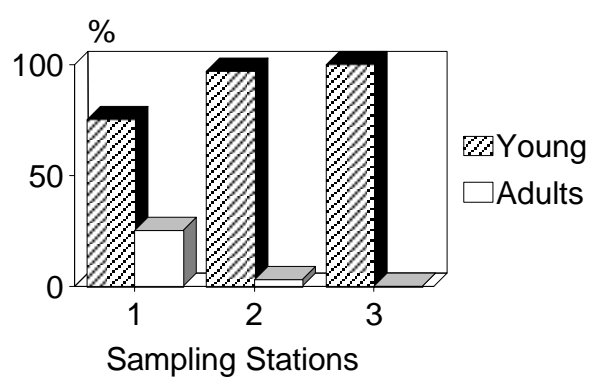

Figure 4 - Occurrence of young and adults of Hypostomus punctatus in three sampling stations. 


\section{DISCUSSION}

Hypostomus punctatus was present and persistent along the whole stream. This was also verified for $H$. ancistroides in several rivers of the Tietê and Paranapanema basins (SP) (E. P. Caramaschi, personal communication), but it was not recorded as persistent in the superior area of the small stream "Barra Funda" (SP) (Garutti, 1988), who verified $H$. ancistroides presented variation in relation to the time of the year, with tendency to increase at the rainy time. In the Ubatiba stream, $H$. punctatus presented variation of occurrence and perseverance in relation to the sampling place, with an increase from the head-water to the mouth. Power (1984), studying Ancistrus, verified that the density and the individuals' abundance were higher in open areas, with less adjacent vegetation, where, due to larger light incidence, the productivity was higher. This could be an explanation for the larger incidence of $H$. punctatus, which eats basically algae (Costa, 1987) in the inferior extension of the stream.

The recruitment of young was indicated by the frequencies superior to $50 \%$ in the class of length $1.0 \mathrm{~cm}$ to $2.5 \mathrm{~cm}$, between November and March, corroborating the results of Menezes \& Caramaschi (1994) who verified the reproductive period for the species in this stream between October and March.

In the Ubatiba stream, there was prevalence of young $(97 \%)$ in the samples. Antoniutti et al. (1985) verified prevalence of adults of $H$. albopunctatus in the studied extension of the Jaguari river (SP), and probably because of the selectivity of fishing equipment, they didn't find fishes with length inferior to $8.0 \mathrm{~cm}$. Garutti (1988), on the other hand, didn't collect individuals of $H$. ancistroides longer than $11.0 \mathrm{~cm}$ and the fishes were collected mainly close to vegetation. The same species was collected in the riparian vegetation by Uieda (1984). Costa (1987) recorded it as microhabitat of $H$. punctatus in the Matogrosso river (RJ), and no fish was found with length superior to $5.4 \mathrm{~cm}$. In the Ubatiba stream, younger $H$. punctatus occurred adhered to the submerged vegetation, while adults were collected mainly in rapids with rocky bottom and in pools among submerged branches. Adults also occurred in holes in the palisades, which hindered considerably their capture. Other authors observed this behaviour for other species of Hypostomus (e.g. Garutti, 1988).

The local process of distribution of Hypostomus punctatus in the Ubatiba stream is associated with the occurrence of different microhabitats along the stream. Thus, young fishes tend to prevail in areas with abundant riparian vegetation, where they take refuge, being adhered by their mouth to the submerged herbaceous leaves; the adults are distributed as in rocky habitats, with larger current, as in lentic ones, with vegetable material, and in holes in palisades.

Menezes \& Caramaschi (1994) suggested the importance of the transport of eggs, larvae and small fishes down by torrential rains to justify the largest incidence of younger Hypostomus punctatus in the inferior extension of the Ubatiba stream. We confirmed this hypothesis and verified the adults' occurrence just in the superior extension of the stream. We suppose individuals move up stream with the growth, and occupy diversified habitats.

\section{ACKNOWLEDGEMENTS}

We thank to D.A.Halboth, J.H.C.Gomes, J.M.R.Aranha and L.M.Soares from Lab. of Ecology of Vertebrates/UFRJ for much help in the field and lab works. FINEP/UFRJ, process $\mathrm{n}^{\circ}$ 4.2.87.0588.00.

\section{RESUMO}

Exemplares de Hypostomus punctatus foram coletados entre Junho/1987 e Julho/1988, em três estações de coleta com diferentes características, ao longo do rio Ubatiba (Maricá, Rio de Janeiro). As estações 2 and 3 foram mais similares entre si (50\% similaridade). A espécie foi frequente e constante em todas as estações de coleta. Os peixes variaram de 1,0 a $22,2 \mathrm{~cm}$ de comprimento padrão. A ocorrência de diferentes classes de tamanho ao longo do rio está provavelmente relaciomada ao tipo de ambiente. Jovens predominaram na amostra total e foram coletados principalmente próximos à vegetação marginal submersa. Adultos ocorreram apenas nas estações 1e 2 , sendo mais frequentes em corredeiras com substrato rochoso e entre galhadas submersas em poças. 


\section{REFERENCES}

Agostinho, A.A., Barbieri, G. Verani, J.R. \& Agostinho, C.S. (1986), Ciclo reprodutivo e primeira maturação de Rhinelepis aspera (Agassiz, 1829) (Teleostei, Loricariidae) no rio Paranapanema. Rev. UNIMAR, 8(1):17-27

Angelescu, V. \& Gneri, F.S. (1949), Adaptaciones del aparato digestivo al régimen alimenticio de algunos peces del rio Uruguay y del rio de la Plata. Rev. Inst. Nac. de Investigación de las Ciênc. Nat., I(6): 162-272

Antoniutti, D.M.; Ranzani-Paiva, M.J.T. \& Godinho, H. (1985), Estrutura da população do cascudo, Plecostomus albopunctatus, Regan, 1908 (Osteichthyes, Loricariidae) do rio Jaguari, São Paulo, Brasil. Bol. Inst. Pesca, 12(4): 121-131

Aranha, J.M.R. \& Caramaschi, E.P. (1997), Distribuição longitudinal e ocupação espacial de quatro espécies de Cyprinodontiformes no rio Ubatiba, Maricá, RJ. Acta Biológica Paranaense, 26(1, 2, 3, 4):125-140

Aranha, J.M.R., Caramaschi, E.P. \& Caramaschi, U. (1993), Ocupação espacial, alimentação e época reprodutiva de duas espécies de Corydoras Lacépède (Siluroidei, Callichthyidae) coexistentes no rio Alambari (Botucatu, São Paulo). Revta. bras. Zool., 10(3): 453-466

Buck, S. \& Sazima, I. (1995), An assemblage of mailed catfishes (Loricariidae) in southeastern Brazil: distribution, activity, and feeding. Icthyol. Explor. Freshwaters, 6(4): 325-332

Costa, W.J.E.M. (1984), Peixes fluviais do sistema lagunar de Maricá, Rio de Janeiro, Brasil. Atlântica, Rio Grande. 7: 65-72

Costa, W.J.E.M. (1987), Feeding habitats of a fish community in a tropical coastal stream, Rio Mato Grosso, Brazil. Studies on Neotropical Fauna and Environment, 22(3): 145-153

Dajoz, R. (1978), Ecologia geral. $3^{\mathrm{a}}$ ed. Ed. Vozes, Petrópolis. 472p

Garutti, V. (1988), Distribuição longitudinal da ictiofauna em um córrego da região noroeste do estado de São Paulo, bacia do rio Paraná. Rev. Brasil. Biol., 48(4): 747-759

Krebs, C.J. (1989), Ecological Methodology. Harper \& Row Publ. 654p
Lowe McCconnell, R.H. (1975), Fish communities in tropical freshwater: their distribution, ecology and evolution. Longman, 337p

Lyons, J. \& Schneider, D.W. (1990), Factors influencing fish distribution and community structure in a small coastal river in southwestern Costa Rica. Hidrobiologia, 203: 1-14

Mazzoni, R. \& Caramaschi, E.P. (1997), Spawning season, ovarian development and fecundity of Hypostomus affinis (Osteichthyes, Loricariidae). Rev. Brasil. Biol., 57(3): 455-462

Menezes, M.S. \& Caramaschi, E.P. (1994), Características reprodutivas de Hypostomus gr. $H$. punctatus no rio Ubatiba, Maricá, RJ (Osteichthyes, Siluriformes). Rev. Brasil. Biol., 54(3): 503-513

Power, M.E. (1984), Habitat quality and the distribution of algae-grazing catfish in a Panamanian stream. Journal of Animal Ecology, 53: 357-374

Romesburg, H.C. (1990), Cluster analysis for researches. Robert E. Krieger, Publishing Company. 334 p

Schäefer, S.A. (1987), Osteology of Hypostomus plecostomus (Linnaeus), with a phylogenetic analysis of the loricariid subfamilies (Pisces, Siluroidei). Contr. Science, Natural History Mus. Los Angeles County., 394: 1-31

Sheldon, A.L. (1968), Species diversity and longitudinal succesion in stram fishes. Ecology, 49(2): 193-198

Siegel, S. (1981), Estatística não paramétrica para as ciências do comportamento. McGraw-Hill. $350 \mathrm{p}$

Uieda, V.S. (1984), Ocorrência e distribuição dos peixes em um riacho de água doce. Rev. Brasil. Biol., 44(2): 203-213

Whiteside, B.G. \& McNatt, R.M. (1972), Fish species diversity in relation to stream order and physicochemical conditions in the Plum Creek drainage basin. The Amer. Midl. Nat., 88(1): 90-101

Received: February 08, 1999; Revised: February 18, 1999; Accepted: December 23, 1999. 